\title{
Effect of rice bran as a replacement for oat grain in energy and nitrogen balance, methane emissions, and milk performance of Murciano-Granadina goats
}

\author{
P. Criscioni and C. Fernández ${ }^{1}$ \\ Animal Science Department, ACUMA Research Center, Polytechnic University of Valencia, 46022 Valencia, Spain
}

\begin{abstract}
The objective of this experiment was to study the effects of substituting oat grain with rice bran on energy, nitrogen and carbon balance, methane emissions, and milk performance in dairy goats. Ten MurcianoGranadina dairy goats in late lactation $(46.1 \pm 3.07$ $\mathrm{kg}$ ) were assigned to 2 treatments in a crossover design, where each goat received both treatments in 2 periods. One group of 5 goats was fed a mixed ration with 379 $\mathrm{g}$ of oat grain $/ \mathrm{kg}$ of dry matter (O diet) and the other group of 5 goats was fed a diet that replaced oat grain with $379 \mathrm{~g} / \mathrm{kg}$ dry matter of rice bran (RB diet). Diets were formulated to be isoenergetic and isoproteic, so bypass fat was added to reach the same amount of energy in both diets. The goats were allocated to individual metabolism cages. After $14 \mathrm{~d}$ of adaptation, feed intake, total fecal and urine outputs, and milk yield were recorded daily over a 5-d period. Then, gas exchange measurements were recorded individually by a mobile open-circuit indirect calorimetry system using a head box. Dry matter intake was different for both diets $[1.83 \pm 0.11$ vs. $1.61 \pm 0.08$ (means \pm SD), for $\mathrm{O}$ and $\mathrm{RB}$, respectively]. Metabolizable energy intake and heat production were not significantly different between diets, with average values of 1,254 [standard error of the mean $(\mathrm{SEM})=110.0]$ and $640(\mathrm{SEM}=$ 21.0) $\mathrm{kJ} / \mathrm{kg}$ of $\mathrm{BW}^{0.75}$, respectively. Significant differences were found in milk fat content (5.3 and 6.9\%, $\mathrm{SEM}=0.36$; for $\mathrm{O}$ and $\mathrm{RB}$, respectively) and milk fatty acids: medium-chain fatty acids (17.17 vs. 12.90 $\mathrm{g} / 100 \mathrm{~g}, \mathrm{SEM}=0.969$; for $\mathrm{O}$ and $\mathrm{RB}$, respectively) and monounsaturated fatty acids (20.63 vs. $28.29 \mathrm{~g} / 100 \mathrm{~g}$, $\mathrm{SEM}=1.973$; for $\mathrm{O}$ and $\mathrm{RB}$, respectively). Enteric $\mathrm{CH}_{4}$ emission was lower for the RB diet (23.2 vs. $30.1 \mathrm{~g} / \mathrm{d}$, $\mathrm{SEM}=2.14$; for $\mathrm{O}$ and $\mathrm{RB}$, respectively), probably because of the higher lipid content in $\mathrm{RB}$ diets than O diets (11.7 vs. $4.1 \%$, respectively). Lactating goats utilized RB without detrimental effects on energy me-
\end{abstract}

Received February 16, 2015.

Accepted September 16, 2015.

${ }^{1}$ Corresponding author: cjfernandez@dca.upv.es tabolism. Higher milk fat and lower $\mathrm{CH}_{4}$ emissions were observed with the RB diet compared with the $\mathrm{O}$ diet.

Key words: lactating goat, rice bran, energy balance, methane emissions

\section{INTRODUCTION}

Most of the concentrates for dairy ruminants are based on cereals. Cereal grains are the most common sources of readily available energy for livestock and comprise up to $60 \%$ of the total diet for high-yielding dairy ruminants. On the other hand, given the ability of ruminal microorganism to degrade fiber, some byproducts of other agricultural and industrial process are used to replace cereal (starch is replaced with highly digestible fibers as a main source of energy). One such byproduct is rice bran, with an estimated world production of 50 million tonnes (FAOSTAT, 2014).

Rice bran is obtained from the grain milling process, representing 5 to $8 \%$ of the total grain. Chemical analysis of rice bran varies widely, containing 11 to $14 \% \mathrm{CP}$, 16 to $21 \%$ NDF, and 21 to $28 \%$ of starch and minerals such as iron (0.015\%), phosphorus (1.35\%), and magnesium $(0.80 \%)$. Rice bran differs from other byproducts in having higher levels of ether extract (EE), at 12 to $18 \%$. The main fatty acids in rice bran oil are palmitic (21-26\%), linoleic (31-33\%), and oleic (37-42\%) acids (Warren and Farrell, 1990; Oliveira et al., 2011).

Rice byproducts (rice straw, rice bran, heat rice bran, defatted rice bran) have been studied in cattle, sheep, and steers (Forster et al., 1994; Cao et al., 2010; Zhao et al., 1996). The effects of including rice bran in mixed diets upon intake, digestibility, energy, $\mathrm{N}$ and $\mathrm{C}$ balance, and milk performance of lactating goats have not been well investigated. Therefore, our aim was compare 2 mixed diets containing the same forage and replacing oat grain with rice bran in the concentrate.

\section{MATERIALS AND METHODS}

The experimental procedures were approved by the Committee on Animal Use and Care at the Polytechnic University of Valencia (Valencia, Spain) and follow 
Table 1. Ingredients and chemical composition (means $\pm \mathrm{SD}$ ) of the mixed diets

\begin{tabular}{|c|c|c|c|c|}
\hline \multirow[b]{2}{*}{ Item $^{1}$} & \multirow[b]{2}{*}{ Oat $(\mathrm{O})$} & \multirow[b]{2}{*}{ Rice bran (RB) } & \multicolumn{2}{|c|}{ Diet $^{2}$} \\
\hline & & & $\mathrm{O}$ & $\mathrm{RB}$ \\
\hline \multicolumn{5}{|l|}{ Ingredients, $\mathrm{g} / \mathrm{kg}$ of $\mathrm{DM}$} \\
\hline Alfalfa hay & & & 350 & 350 \\
\hline Oats & 1,000 & & 379 & \\
\hline Rice bran & & 1,000 & & 379 \\
\hline Barley & & & 182 & 197 \\
\hline Soy meal $(44 \% \mathrm{CP})$ & & & 64 & 29 \\
\hline Bypass fat & & & 15 & 33 \\
\hline Calcium carbonate & & & 3.3 & 3.3 \\
\hline Sodium chloride & & & 1.2 & 4.1 \\
\hline Premix & & & 5.4 & 5.4 \\
\hline \multicolumn{5}{|l|}{ Chemical composition, $\%$ of DM } \\
\hline DM & $90.0 \pm 5.4$ & $89.7 \pm 3.6$ & 88.8 & 89.1 \\
\hline Ash & $2.9 \pm 0.2$ & $8.2 \pm 0.4$ & 7.9 & 9.7 \\
\hline $\mathrm{OM}$ & & & 92.1 & 90.3 \\
\hline $\mathrm{CP}$ & $8.4 \pm 0.4$ & $13.8 \pm 0.8$ & 15.3 & 16.1 \\
\hline Ether extract & $4.9 \pm 0.3$ & $13.9 \pm 0.8$ & 4.1 & 11.7 \\
\hline $\mathrm{NDF}$ & $31.2 \pm 1.9$ & $17.9 \pm 0.9$ & 27.2 & 22.8 \\
\hline $\mathrm{ADF}$ & $17.1 \pm 0.5$ & $9.1 \pm 0.4$ & 12.4 & 10.4 \\
\hline $\mathrm{NFC}^{2}$ & & & 45.5 & 39.8 \\
\hline Starch & $37.0 \pm 1.9$ & $27.1 \pm 1.4$ & 28.2 & 21.6 \\
\hline Carbon & & & 43.5 & 44.6 \\
\hline Gross energy, MJ/kg of DM & & & 17.9 & 19.4 \\
\hline
\end{tabular}

${ }^{1}$ Bypass fat of palm fatty acid distillate (Norel Animal Nutrition, Norel S.A., Spain). Premix (NACOOP S.A., Madrid, Spain) composition (per kg of premix): Se, $40 \mathrm{mg}$; I, $250 \mathrm{mg}$; Co, $80 \mathrm{mg}$; Cu, 3,000 mg; Fe, 6,000 mg; Zn, 23,400 mg; Mn, 29,000 mg; S, 60,000 mg; Mg, 60,000 mg; vitamin A, 2,000,000 IU; vitamin $\mathrm{D}_{3}, 400,000 \mathrm{IU}$; vitamin E, 2,000 mg; nicotinic acid, 10,000 mg; choline, 20,300 mg.

${ }^{2} \mathrm{NFC}=100-(\mathrm{NDF}+\mathrm{ash}+\mathrm{CP}+$ ether extract $)$.

the codes of practice for animals used in experimental works proposed by the European Union (2003).

\section{Animals and Diets}

The experiment was conducted at the Animal Science Department Experimental Farm (ACUMA Research Center, Valencia, Spain). Ten multiparous mature Murciano-Granadina dairy goats in late lactation were selected and divided into 2 homogeneous groups of 5 goats based on similar BW $(46.1 \pm 3.07 \mathrm{~kg}$ of BW), milk production in previous lactations $(661.5 \pm 44 \mathrm{~kg}$ of milk per $210 \pm 30 \mathrm{~d}$ of lactation, on average), and milk yield at the beginning of the experiment $(2,375$ $\pm 375.1 \mathrm{~g}$ of milk per day, on average), in a crossover design (2 treatments crossed with 2 periods). Treatments consisted of 2 different mixed rations (Table 1). Goats were fed daily with $0.800 \mathrm{~kg}$ of alfalfa hay and $1.5 \mathrm{~kg}$ of concentrate (the forage:concentrate ratio was 35:65, expressed as percentage). The concentrate and premix were mixed and pelleted. One group was fed concentrate with $379 \mathrm{~g} / \mathrm{kg}$ of DM of oat grain ( $\mathbf{O}$ diet) and the other with rice bran (RB diet). Nutrient requirements followed the recommendations of Lachica and Aguilera (2003) and Calsamiglia et al. (2009) for goats in lactation. In an attempt to feed isoenergetic diets, bypass fat was added to each diet; that is, diets were formulated on an energy basis using book values for chemical composition of ingredients (FEDNA, 2010). The chemical composition of oats, rice bran, and the whole mixed diet (forage and pelleted concentrate) is reported in Table 1. After feed manufacturing and chemical analyses of diets, we found that the diets were not isoenergetic and that the RB diet had greater gross energy value. Half of the daily ration was offered at $0800 \mathrm{~h}$ and half at $1600 \mathrm{~h}$. Goats had free access to water.

\section{Experimental Schedule and Measurements}

Apparent total-tract digestibility, gas exchange, energy partitioning, $\mathrm{C}$ and $\mathrm{N}$ balance, oxidation of nutrients, and milk composition and yield were determined. The experiment was conducted in a crossover design in two 30-d periods. During the adaptation period, goats were fed the experimental diets in pens for $7 \mathrm{~d}$ and then allocated to individual metabolism cages at thermoneutrality $\left(20-23^{\circ} \mathrm{C}\right.$ determined by Hobo data loggers, Onset Corp., Cape Cod, MA) for another $7 \mathrm{~d}$. Next, data on amounts of feed offered and refused and total fecal, urine, and milk outputs were recorded daily for each goat during a 5 -d period; BW was recorded at the beginning and end of the period. Feces were collected in wire-screen baskets placed under the floor of 
the metabolism crates, and urine was collected through a funnel into plastic buckets containing $100 \mathrm{~mL}$ of $10 \%$ ( vol $/ \mathrm{vol}$ ) $\mathrm{H}_{2} \mathrm{SO}_{4}$ to acidify the urine of each goat. The acidification of urine was necessary to prevent microbial degradation and loss of volatile ammonia- $\mathrm{N}$ $\left(\mathrm{NH}_{3}-\mathrm{N}\right)$. Representative samples $(10 \%)$ of diet, feces, and urine were collected over 5 consecutive days, stored at $-20^{\circ} \mathrm{C}$, and pooled for chemical analysis. The goats were milked once daily at $0800 \mathrm{~h}$ with a portable milking machine (Flaco model DL-170, J. Delgado S.A., Ciudad Real, Spain). Immediately after milking, the individual milk yield was measured and a $10 \%$ sample was placed in a bottle and frozen until analysis. In addition, samples were collected into plastic vials that contained $20 \mathrm{mg}$ of potassium dichromate as a preservative and taken to the Interprofessional Dairy Laboratory of the Valencia Community Region (LICOVAL, Valencia, Spain) for compositional analysis (DM, CP, fat, and lactose). Ruminal fluid samples were collected by stomach tube before the morning feeding on the last day of the apparent digestibility trial. Ruminal fluid $\mathrm{pH}$ was immediately determined using a portable $\mathrm{pH}$ meter (model 265A, Orion Research Inc., Beverly, MA). A ruminal fluid sample was acidified with $50 \% \mathrm{H}_{2} \mathrm{SO}_{4}$ and frozen until later determination of $\mathrm{NH}_{3}-\mathrm{N}$. Samples for analysis of VFA were mixed with $\mathrm{H}_{3} \mathrm{PO}_{4}$ and kept frozen until analysis.

Gas exchange was measured for each goat during $24 \mathrm{~h}$ (5 goats/treatment) by an indirect calorimetric system based on a ventilated head-box designed for small ruminants. To this end, therefore, each digestibility-balance period include 10 days of gas exchange determinations in the incomplete crossover design. The respirometry system was equipped with a head hood, a flow meter (Thermal Mass Flowmeter Sensyflow VT-S, ABB, Alzenau, Germany), and air suction provided by a centrifugal fan (CST60 Soler Palau Inc., Parets del Vallès, Barcelona, Spain). The concentrations of $\mathrm{CH}_{4}$ and $\mathrm{CO}_{2}$ were measured using the infrared principle, and $\mathrm{O}_{2}$ was measured by the paramagnetic principle (Easyflow Gas Analyzer, model 3020, ABB, Alzenau, Germany). Although the unit was an autocalibrated model, the analyzers were calibrated with reference gases before each test. Fernández et al. (2012, 2015) described the mobile open-circuit respirometry system used for these measurements. The whole system was calibrated by injecting pure $\mathrm{N}_{2}$ and $\mathrm{CO}_{2}$ into the head box (McLean and Tobin, 1987), and the calibration factor of $\mathrm{N}_{2}$ and $\mathrm{CO}_{2}$ was determined gravimetrically using a precision scale (mini-SP $0.2-30 \mathrm{~kg}$, Industrial Weighing System, Mobba, Barcelona, Spain). Calibration factors were calculated according to Brockway et al. (1971). Production of $\mathrm{CH}_{4}$ and $\mathrm{CO}_{2}$ and consumption of $\mathrm{O}_{2}$ were calculated as described by Aguilera and
Prieto (1986). An initial atmospheric air sample was collected and the gas concentrations were used as reference for calculations.

\section{Chemical Analysis}

Samples of feed, feed refusals, and feces were first dried in a forced-air oven at $55^{\circ} \mathrm{C}$ for $48 \mathrm{~h}$ and then ground to pass a 1-mm screen before analysis. Urine and milk were dried by lyophilization. Chemical analyses of the diet, refusals, and feces were conducted according to AOAC International (2000) for DM (method 934.01), ash (method 942.05), and EE (method 920.39). The DM of diets and feces was determined by ovendrying at $102 \pm 2^{\circ} \mathrm{C}$ for $24 \mathrm{~h}$. Ash concentration was measured following incineration in an electric muffle furnace at $550^{\circ} \mathrm{C}$ for $6 \mathrm{~h}$. Ether extract was extracted with petroleum ether after acid hydrolysis to recover saponified fat (Soxtec System HT, Tecator, Hillerød, Denmark; 1047 Hydrolyzing Unit and 1043 Extraction Unit). The NDF and ADF were measured in an Ankom Fiber Analyzer (A220, Ankom Technologies, Fairport, NY) according to Mertens (2002) and AOAC International (2000), respectively. The NDF was determined using sodium sulfite and $\alpha$ amylase. The NFC content of diets was calculated by difference method based on chemical analysis of individual feeds according to NRC (2001): NFC $=100-\mathrm{NDF}-$ ash $-\mathrm{CP}-\mathrm{EE}$. The gross energy (GE) content of the dried samples (feed, feces, urine, and milk) was analyzed by combustion in an adiabatic bomb calorimeter (Autobomb; Gallenkamp, Loughborough, UK). Starch content was determined by enzymatic method ( $\alpha$-amylase obtained from Sigma-Aldrich, Steinheim, Germany) according to Batey (1982). Carbon and nitrogen were analyzed according to the Dumas principle (TruSpec CN; Leco Corporation, St. Joseph, MI). Multiplying N by a factor of 6.25 converted the results to CP.

Milk composition (fat, protein, lactose, citrate, and total milk solids content) was analyzed with an infrared analyzer (MilkoScan FT120, Foss Electric, Hillerød, Denmark). Fatty acid methyl esters of total milk lipids were prepared directly as previously described O'Fallon et al. (2007). The FAME were analyzed in a Focus Gas Chromatograph (Thermo, Milan, Italy) equipped with a split/splitless injector and a flame-ionization detector. Separation of FAME was performed in a fused silica capillary column SP 2560 (Supelco, Bellefont, PA; 100 $\mathrm{m} \times 0.25 \mathrm{~mm} \times 0.2 \mu \mathrm{m}$ film thickness). The carrier gas was helium at a linear velocity of $20 \mathrm{~cm} / \mathrm{s}$. The samples were injected with a split ratio of $1 / 100$. The initial oven temperature was set at $140^{\circ} \mathrm{C}$ held for $5 \mathrm{~min}$, increased to $240^{\circ} \mathrm{C}$ at $4^{\circ} \mathrm{C} / \mathrm{min}$, and finally maintained at that temperature for $30 \mathrm{~min}$. Both detector and injector 
temperatures were set at $260^{\circ} \mathrm{C}$. A subset of milk samples was collected and analyzed for BHB, glucose, uric acid, and milk urea. Milk BHB was analyzed using the enzymatic oxidation of the metabolite, and a coupled reaction was determined by fluorometry (Larsen and Nielsen, 2005). Milk urea acid was analyzed following procedures described by Larsen and Moyes (2010). Milk urea was analyzed using flow injection analyses following the manufacturer instructions (Foss Tecator AB, Höganäs, Sweden). Glucose was determined according to standard procedures (Siemens Diagnostics Clinical Methods for Advia 1650) using an autoanalyzer (Advia 1650 Chemistry system, Siemens Medical Solutions, Tarrytown, NY).

The $\mathrm{NH}_{3}-\mathrm{N}$ content of ruminal fluid samples was analyzed by the Kjeldahl procedure (2300 Kjeltec Analyzer Unit, Foss Tecator, Hillerød, Denmark). Determination of ruminal VFA was based on the method described by Jouany (1982) using a gas chromatograph (Fisons 8000 series; Fisons Instruments SpA, Milan, Italy) equipped with a split/splitless injector and flame-ionization detector.

\section{Calculations}

Metabolizable energy intake (MEI) was calculated as the difference between GE intake and energy losses in feces, urine and $\mathrm{CH}_{4}$ (with an energy equivalent value of $39.5 \mathrm{~kJ} / \mathrm{L}$ of $\mathrm{CH}_{4}$; Brouwer, 1965).

Heat production ( $\mathbf{H P})$ was determined from measurements of $\mathrm{O}_{2}$ consumption, $\mathrm{CO}_{2}$ and $\mathrm{CH}_{4}$ production, and urine $\mathrm{N}$ ( $\left.\mathbf{N}_{\text {urine }}\right)$, using the equation of Brouwer (1965):

$$
\begin{aligned}
\mathrm{HP}(\mathrm{kJ})= & 16.18 \times \mathrm{O}_{2}+5.02 \times \mathrm{CO}_{2}-2.17 \\
& \times \mathrm{CH}_{4}-5.99 \times \mathrm{N}_{\text {urine }}
\end{aligned}
$$

where gases were expressed in liters per day and $\mathrm{N}_{\text {urine }}$ in grams per day. Body tissue energy $\left(\mathbf{R E}_{\text {body }}\right)$ was calculated as MEI - HP - milk energy $\left(\mathbf{E}_{\text {milk }}\right)$.

The energy associated with the oxidation of protein (OXP), carbohydrate (OXCHO), and fat (OXF) was calculated by the method of Brouwer (1958) and Chwalibog et al. (1997) for ruminants. The $\mathrm{CO}_{2}$ production from oxidation $\left(\mathbf{C O}_{2 \mathrm{x}}\right)$ was calculated as $\mathrm{CO}_{2}$ - $\left(2 \times \mathrm{CH}_{4}\right)$, according to Fahey and Berger (1988). The calculations were carried out as follows:

$$
\begin{gathered}
\mathrm{OXP}=6.25 \times \mathrm{N}_{\text {urine }} \times 18.42(\mathrm{~kJ} / \mathrm{g}), \\
\mathrm{OXCHO}=\left(-2.968 \times \mathrm{O}_{2}+4.174 \times \mathrm{CO}_{2 \mathrm{x}}\right. \\
\left.-2.446 \times \mathrm{N}_{\text {urine }}\right) \times 17.58(\mathrm{~kJ} / \mathrm{g}),
\end{gathered}
$$

$$
\begin{aligned}
\mathrm{OXF}=( & \left(1.719 \times \mathrm{O}_{2}-1.719 \times \mathrm{CO}_{2 \mathrm{x}}-1.963\right. \\
& \left.\times \mathrm{N}_{\text {urine }}\right) \times 39.76(\mathrm{~kJ} / \mathrm{g}) .
\end{aligned}
$$

Then, the HP from oxidation $(\mathbf{H P x})$ was

$$
\begin{gathered}
\mathrm{HPx}(\mathrm{kJ})=16.18 \times \mathrm{O}_{2}+5.02 \\
\times \mathrm{CO}_{2 \mathrm{x}}-5.99 \times \mathrm{N}_{\text {urine }} .
\end{gathered}
$$

Again, gases were expressed in liters per day and $\mathrm{N}_{\text {urine }}$ in grams per day. Heat of fermentation (HPf) was estimated by subtracting HP from HPx. The nonprotein respiratory quotient from oxidation of nutrients (RQnpx) was determined as follows: RQnpx $=\left[\mathrm{CO}_{2 \mathrm{x}}\right.$ $\left.-\left(\mathrm{N}_{\text {urine }} \times 6.25 \times 0.774\right)\right] /\left[\mathrm{O}_{2}-\left(\mathrm{N}_{\text {urine }} \times 6.25 \times 0.957\right)\right]$. For $\mathrm{C}$ and $\mathrm{N}$ balance, we followed the equations and values proposed by McLean and Tobin (1987), and the grams retained in protein $\left(\mathbf{R}_{\text {protein }}\right)$ and fat $\left(\mathbf{R}_{\text {fat }}\right)$ were calculated.

The efficiency of use of ME for lactation was calculated according to AFRC (1993). Energy lost from the body, indicating mobilization of body fat reserves in support of milk secretion, was assumed to be used for milk synthesis with an efficiency of 0.84 and the concomitant energy storage during lactation was taken to be 0.95 times the milk secretion efficiency. Consequently, the corrected milk energy was estimated as $\mathrm{E}_{\text {milk }}+(0.84 \times$ negative energy retention $)+(1.05$ $\times$ positive energy retention). The efficiency of use of ME for milk production $\left(\mathbf{k}_{\mathbf{l}}\right)$ was calculated as corrected milk energy/(ME - $\left.\mathbf{M E}_{\mathrm{m}}\right)$, with $\mathrm{MEm}$ being the metabolizable energy for maintenance, which was obtained from the estimation of Aguilera et al. (1990) for Granadina goats from both positive and negative energy retentions $\left(401 \mathrm{~kJ} / \mathrm{kg}\right.$ of $\left.\mathrm{BW}^{0.75}\right)$. Net energy for lactation $\left(\mathrm{NE}_{\mathrm{L}}\right)$ was computed as MEI $\times \mathrm{k}_{\mathrm{l}}$.

\section{Statistical Analysis}

The effects of substituting oat with rice bran on intake, digestibility, ruminal fermentation, milk performance, energy and $\mathrm{C}$ and $\mathrm{N}$ balances, and oxidation of nutrients were analyzed using the PROC MIXED of SAS Institute (2001). The experiment was conducted as a crossover design: each goat received both treatments in 2 periods; goat served as the experimental unit for all data. The model for the dependent variables included the fixed effect of diet and period, with goat as random effect. The following statistical model was used: $\mathrm{Y}=$ $\mu+\mathrm{D}+\mathrm{T}+$ goat $+\varepsilon$, where $\mathrm{Y}$ is the dependent variable; $\mu$ is the overall mean; $\mathrm{D}$ and $\mathrm{T}$ are the fixed effects of diet and period of time, respectively; goat is the random effect of goat; and $\varepsilon$ is the random error. 
Least squares means are reported throughout and differences were considered significant at $P<0.05$.

\section{RESULTS AND DISCUSSION}

No significant effect was observed for period in the crossover design. The average value for the calibration factor was $1.0055 \pm 0.00139(\mathrm{n}=5)$ and $0.9936 \pm$ $0.00953(\mathrm{n}=5)$ for $\mathrm{O}_{2}$ and $\mathrm{CO}_{2}$, respectively.

\section{Feed Intake, Digestibility, and Rumen Fermentation}

The mixed diets were formulated based on book values of FEDNA (2010) to reach isoenergetic and isoproteic balance (average values of $15.7 \%$ of $\mathrm{CP}$ on DM basis). However, after feed manufacturing, samples of each diet were analyzed in the laboratory and we determined that the diets were not isoenergetic and the RB diet presented greater gross energy values (17.9 \pm 0.89 vs. $19.4 \pm 1.17 \mathrm{MJ} / \mathrm{kg}$ of $\mathrm{DM}$ in $\mathrm{O}$ and $\mathrm{RB}$ diets, respectively). The main difference among diets was the source of carbohydrate in oat grain and rice bran, although RB diet had twice the amount of bypass fat as the $\mathrm{O}$ diet. Rice bran has a large proportion of broken rice (starch), oil, and protected protein (Elliot et al., 1978). The chemical composition (Table 1) was not equal, and NDF, ADF, NFC, and starch were lower in $\mathrm{RB}$ than in $\mathrm{O}$; ether extract was greater in $\mathrm{RB}$ than O ( $11.7 \%$ vs. $4.1 \%$, respectively).

Intake and total-tract apparent digestibility of nutrients by dairy goats during late lactation are shown in Table 2. Dry matter intake differed $(P<0.05)$ between diets $(1.83 \pm 0.11$ vs. $1.61 \pm 0.08 \mathrm{~kg} / \mathrm{d}$, for $\mathrm{O}$ and $\mathrm{RB}$ respectively), possibly because the animals' intake was regulated by energy requirements, so less of the richest diet was eaten. Also, the high content of fat on diet RB reduced DMI, as has been indicated by other authors supplementing rice bran oil in dairy cows because reduced gut motility (Lunsin et al., 2012). No differences were found for DM apparent digestibility with a value for the $\mathrm{RB}$ diet of $73.9 \%(\mathrm{SEM}=1.57)$, similar to the rice bran value of $70 \%$ found by Van Soest (2006). Apparent digestibility coefficients of fiber were higher $(P<0.05)$ in $\mathrm{RB}$ than in $\mathrm{O}(48.7$ vs. $34.7 \%, \mathrm{SEM}=4.42$; for $\mathrm{NDF}$, and 48.1 vs. $35.0 \%$, SEM $=4.16$; for $\mathrm{ADF}$, respectively). High fat content in the diet decreases OM and fiber degradability and reduces fermentable substrate. It is expected that high levels of fat would inhibit fiber digestion, possibly by coating food particles and preventing bacterial attachment (Palmquist and Jenkins, 1980). In the present work, the RB diet showed increased fiber digestibility even though it had $11.7 \%$ fat, and could be related to the lower amount of fiber and DMI in the RB diet than the
Table 2. Body weight, intake, and apparent digestibility coefficients of Murciano-Granadina goats $(\mathrm{n}=10)$ during late lactation according to the type of diet

\begin{tabular}{lcccc}
\hline & \multicolumn{2}{c}{ Diet } & & P-value \\
\cline { 2 - 3 } \cline { 5 - 5 } Item & Oats & Rice bran & SEM & Diet \\
\hline BW, kg & 45.8 & 46.4 & 1.35 & 0.84 \\
DMI, kg/d & 1.83 & 1.61 & 0.112 & 0.047 \\
Digestibility, \% of DM & & & & \\
DM & 70.4 & 73.9 & 1.57 & 0.30 \\
OM & 72.2 & 76.3 & 1.52 & 0.19 \\
CP & 71.3 & 72.6 & 1.45 & 0.70 \\
Ether extract & 67.2 & 79.8 & 3.68 & 0.09 \\
NDF & 34.7 & 48.7 & 4.42 & 0.12 \\
ADF & 35.0 & 48.1 & 4.16 & 0.12 \\
NFC & 95.0 & 94.3 & 0.31 & 0.36 \\
Starch & 98.1 & 97.1 & 0.26 & 0.06 \\
Gross energy & 72.8 & 77.1 & 1.53 & 0.19 \\
\hline
\end{tabular}

O diet (see Tables 1 and 2, respectively). Zhao et al. (1996) reported, in steers, that the addition of fat to high-concentrate diets containing $12 \%$ ADF could have shifted the site of $\mathrm{OM}$ digestion from the rumen to the intestine. Higher digestibility $(P<0.05)$ was found in $\mathrm{RB}$ than in $\mathrm{O}$ for fat $(79.8$ vs. $67.2 \%, \mathrm{SEM}=3.68$; respectively) and the digestibility of starch was almost complete.

Results from rumen liquor samples are shown in Table 3. The average rumen $\mathrm{pH}$ never decreased below 6.2 , so the values obtained can be considered sufficiently high to maintain normal rumen fermentation (Ørskov and Fraser, 1975). Goats fed O (slightly greater amount of structural and nonstructural carbohydrates and lower fat than RB) had a higher $\mathrm{pH}(P<0.05)$ and a lower $\mathrm{NH}_{3}-\mathrm{N}(P<0.05)$ concentration compared with goats fed RB (15.8 vs. $23.3 \mathrm{mg} / \mathrm{dL}, \mathrm{SEM}=2.00$; for $\mathrm{O}$ and $\mathrm{RB}$, respectively). No effect of treatment on VFA was observed, and differences in $\mathrm{NH}_{3}-\mathrm{N}$ concentration might suggest partial inhibition of microbial synthesis by the rice bran fat. The ruminal $\mathrm{NH}_{3}-\mathrm{N}$ and VFA values from our study are within the range of those found in other studies with goats fed byproducts (Romero-Huelva et al., 2012). Therefore, the lower $\mathrm{NH}_{3}-\mathrm{N}$ results for diet $\mathrm{O}$ compared with RB suggest more fermentation activity. We recognize that the starch in rice bran escapes rumen fermentation almost entirely and also drives fat and bypass protein to the duodenum (Elliot et al., 1978).

\section{Energy Balance}

Daily energy balance obtained with the 2 diets is listed in Table 4. No statistically significant differences were observed for GE intake $(1,833 \pm 137.1 \mathrm{~kJ} / \mathrm{kg}$ of $\mathrm{BW}^{0.75}$, on average) and the rest of energy partition, with exception of feces and $\mathrm{CH}_{4}$. Energy losses in feces were higher $(P<0.05)$ for $\mathrm{O}$ than $\mathrm{RB}$, probably associ- 
Table 3. $\mathrm{pH}$, ammonia- $\mathrm{N}\left(\mathrm{NH}_{3}-\mathrm{N}\right)$, and VFA of Murciano-Granadina goats $(\mathrm{n}=10)$ during late lactation according to the type of diet

\begin{tabular}{lrrrrr}
\hline & \multicolumn{2}{c}{ Diet } & & \multirow{2}{*}{$P$-value } \\
\cline { 2 - 3 } \cline { 5 - 6 } Item & Oats & Rice bran & SEM & Diet \\
\hline $\mathrm{pH}$ & 7.3 & 7.0 & 0.08 & 0.03 \\
$\mathrm{NH}_{3}$-N, mg/dL & 15.8 & 23.3 & 2.00 & 0.05 \\
Total VFA, mmol/L & 21.5 & 19.6 & 1.83 & 0.64 \\
Individual VFA, mol/100 mol & & & & \\
$\quad$ Acetic acid & 61.6 & 56.7 & 2.11 & 0.28 \\
Propionic acid & 15.0 & 19.1 & 1.47 & 0.18 \\
Isobutyric acid & 3.3 & 3.0 & 0.48 & 0.85 \\
Butyric acid & 13.0 & 14.0 & 0.85 & 0.63 \\
Isovaleric acid & 3.7 & 3.4 & 0.44 & 0.78 \\
$n$-Valeric acid & 2.3 & 2.5 & 0.39 & 0.84 \\
$n$-Caproic acid & 0.8 & 0.8 & 0.25 & 0.90 \\
Heptanoic acid & 0.5 & 0.5 & 0.18 & 0.92 \\
\hline
\end{tabular}

ated with greater DMI. Urine energy losses were not significantly different between treatments. The $\mathrm{O}$ diet presented significant differences $(P<0.05)$ on energy losses in $\mathrm{CH}_{4}\left(95 \mathrm{~kJ} / \mathrm{kg}\right.$ of $\left.\mathrm{BW}^{0.75}\right)$ compared with the $\mathrm{RB} \operatorname{diet}\left(73 \mathrm{~kJ} / \mathrm{kg}\right.$ of $\left.\mathrm{BW}^{0.75}\right)$, indicating that increasing the level of lipids in diet reduced $\mathrm{CH}_{4}$ production, as indicated by different authors and reviewed by Knapp et al. (2014). No differences between treatments were observed for MEI $\left(1,254 \mathrm{~kJ} / \mathrm{kg}\right.$ of $\mathrm{BW}^{0.75}$, on average; $\mathrm{SEM}=110.0)$. The HP values from our study $(P=$ $0.63 ; 640 \mathrm{~kJ} / \mathrm{kg}$ of $\mathrm{BW}^{0.75}$, on average; $\left.\mathrm{SEM}=21.0\right)$ were within the range of some literature values; for example, Bava et al. (2001) found an average value of $642 \mathrm{~kJ} / \mathrm{kg}$ of $\mathrm{BW}^{0.75}$ for Saanen goats fed mixed diets in late lactation. Tovar-Luna et al. (2010) fed Alpine goats during late lactation with $60 \%$ concentrate and found values of $680 \mathrm{~kJ} / \mathrm{kg}$ of $\mathrm{BW}^{0.75}$. The tissue energy recovered in the body was positive and did not differ between diets $\left(107 \mathrm{~kJ}\right.$ of $\mathrm{RE}_{\text {body }} / \mathrm{kg}$ of $\mathrm{BW}^{0.75}$, $\mathrm{SEM}=$ $68.4)$.

No significant differences were observed between diets for $\mathrm{k}_{1}$ ( 0.72 on average). The value obtained in the present work was similar to that reported by Bava et al. (2001) in Saanen goats (0.73). Aguilera et al. (1990) and Tovar-Luna et al. (2010) found lower values (0.67 and 0.63 , respectively). The increase in $k_{1}$ with increasing dietary fat is well established in the literature and has traditionally been attributed to a decrease in the heat increment of feeding and the relatively low energy cost of the transfer of absorbed fatty acids to milk fat compared with the cost of novo synthesis of fatty acids (Moraes et al., 2015). Furthermore, in our study, we assumed a value of $401 \mathrm{~kJ} / \mathrm{kg}$ of $\mathrm{BW}^{0.75}$ for MEm, but animals in late lactation have lower production and lower metabolic activity of visceral organs for maintenance (i.e., lower MEm) than animals in earlier lactation stages. These factors likely explain the high $\mathrm{k}_{\mathrm{l}}$ obtained in our experiment. Net energy for lactation was expressed as megajoules per kilogram of DM and significant values of $8.4 \pm 0.42$ and $10.2 \pm 0.41$ were found in $\mathrm{O}$ and $\mathrm{RB}$ mixed diets, respectively.

\section{Oxidation of Nutrients}

The proportional contribution to HPx due to oxidation of nutrients is shown in Table 5. Diet had no significant effect on HPx $\left(623 \mathrm{~kJ} / \mathrm{kg}\right.$ of $\mathrm{BW}^{0.75}$, on average; $\mathrm{SEM}=20.2$ ). Numerically lower HPf was found in $\mathrm{RB}$ than $\mathrm{O}$, probably linked to the higher fat content in the RB diet (11.7\%), as we mentioned previously.

The oxidation of nutrients as OXCHO increased $(P$ $<0.05$ ) from 15 to $33 \%$ in diets RB and $\mathrm{O}$, respectively $(\mathrm{SEM}=4.5)$. Consequently, OXF decreased $(P<0.05)$ from 64 to $48 \%$ in $\mathrm{RB}$ and $\mathrm{O}$, respectively ( $\mathrm{SEM}=$ 4.3). A significant difference $(P<0.05)$ was observed for RQnpx, which was significantly lower for RB (0.77) than for O (0.83) with an SEM of 0.015. Chwalibog et al. (1997) reported that an RQnpx $<1$ indicates predominance of OXF versus OXCHO, and under positive energy balance, part of the OXF should originate from ingested carbohydrate (mainly fiber) and diet fat content.

\section{Carbon and Nitrogen Balance}

The daily $\mathrm{C}$ and $\mathrm{N}$ balance and the calculated tissue recovered as protein and fat are given in Table 6. No significant differences were observed in $\mathrm{C}$ intake, feces, or urine. Following the trend observed for methane energy, the $\mathrm{C}$ losses in $\mathrm{CH}_{4}$ were significantly lower with $\mathrm{RB}$ than with $\mathrm{O}\left(1.3\right.$ vs. $1.7 \mathrm{~g} / \mathrm{kg}$ of $\mathrm{BW}^{0.75}$, respectively; $\mathrm{SEM}=0.14$ ) because of the lower $\mathrm{CH}_{4}$ production

Table 4. Daily energy partitioning ( $\mathrm{kJ} / \mathrm{kg}$ of $\mathrm{BW}^{0.75}$ ) of MurcianoGranadina goats $(\mathrm{n}=10)$ during late lactation according to the type of diet

\begin{tabular}{lrrrr}
\hline & \multicolumn{2}{c}{ Diet } & & \multicolumn{1}{c}{$P$-value } \\
\cline { 2 - 3 } Item $^{1}$ & Oats & Rice bran & SEM & Diet \\
\hline GEI & 1,889 & 1,777 & 137.1 & 0.71 \\
$\mathrm{E}_{\text {feces }}$ & 504 & 396 & 35.8 & 0.04 \\
$\mathrm{E}_{\text {urine }}$ & 41 & 50 & 4.9 & 0.41 \\
$\mathrm{E}_{\text {methane }}$ & 95 & 73 & 7.6 & 0.04 \\
MEI & 1,248 & 1,259 & 110.0 & 0.97 \\
HP & 651 & 628 & 21.0 & 0.62 \\
$\mathrm{E}_{\text {milk }}$ & 491 & 524 & 36.0 & 0.67 \\
RE & 107 & 106 & 68.4 & 1.00 \\
\hline
\end{tabular}

${ }^{1} \mathrm{GEI}=$ gross energy intake; $\mathrm{E}_{\text {feces }}, \mathrm{E}_{\text {urine }}$, and $\mathrm{E}_{\text {methane }}=$ energy losses in feces, urine, and methane, respectively; MEI = metabolizable energy intake; $\mathrm{HP}=$ heat production; $\mathrm{RE}_{\text {total }}=$ total recovered energy; $\mathrm{E}_{\text {milk }}=$ recovered energy in milk; $\mathrm{RE}_{\mathrm{body}}=$ recovered energy in tissue $\left(\mathrm{RE}_{\mathrm{body}}\right.$ $\left.=\mathrm{MEI}-\mathrm{HP}-\mathrm{E}_{\mathrm{milk}}\right)$. 
Table 5. Heat production $\left(\mathrm{kJ} / \mathrm{kg}\right.$ of $\left.\mathrm{BW}^{0.75}\right)$ from oxidation and fermentation; daily oxidation $\left(\mathrm{kJ} / \mathrm{kg}\right.$ of $\left.\mathrm{BW}^{0.75}\right)$ of protein, carbohydrate, and fat; and their contribution to the heat production from oxidation substrates (\%) of Murciano-Granadina goats $(\mathrm{n}=10)$ during late lactation according to the type of diet

\begin{tabular}{lccrcc}
\hline & \multicolumn{2}{c}{ Diet } & & \multicolumn{1}{c}{$P$-value } \\
\cline { 2 - 3 } \cline { 5 - 5 } Item $^{1}$ & Oats & Rice bran & & SEM & Diet \\
\hline HPx & 632 & 614 & 20.2 & 0.68 \\
HPf & 19 & 15 & 1.5 & 0.16 \\
OXP & 119 & 126 & 6.2 & 0.62 \\
OXCHO & 211 & 100 & 29.6 & 0.05 \\
OXF & 302 & 388 & 24.1 & 0.07 \\
OXP/HPx & 19 & 21 & 1.2 & 0.49 \\
OXCHO/HPx & 33 & 15 & 4.5 & 0.04 \\
OXF/HPx & 48 & 64 & 4.3 & 0.06 \\
RQnpx & 0.83 & 0.77 & 0.015 & 0.04 \\
\hline IHPx & & &
\end{tabular}

$\overline{{ }^{1} \mathrm{HPx}}=$ heat production from oxidation of nutrients; HPf $=$ heat production of fermentation (HPf $=\mathrm{HP}-\mathrm{HPx}$; Brouwer, 1958); OXP = heat production associated with the oxidation of protein; $\mathrm{OXCHO}=$ heat production associated with the oxidation of carbohydrates; OXF $=$ heat production associated with the oxidation of fat; RQnpx $=$ nonprotein respiratory quotient (unitless) from oxidation of nutrients $\left\{\left[\mathrm{CO}_{2} \mathrm{x}-\left(\mathrm{N}_{\text {urine }} \times 6.25 \times 0.774\right)\right] /\left[\mathrm{O}_{2}-\left(\mathrm{N}_{\text {urine }} \times 6.25 \times 0.957\right)\right]\right.$, where $\mathrm{CO}_{2} \mathrm{x}=\mathrm{CO}_{2}$ production from oxidation and $\mathrm{N}_{\text {urine }}=\mathrm{N}$ in urine $\}$.

with this diet. The $\mathrm{C}$ secreted into the milk was not significantly affected by treatment and the retention of $\mathrm{C}$ was positive $\left(1.5 \mathrm{~g} / \mathrm{kg}\right.$ of $\mathrm{BW}^{0.75}$, on average; SEM $=0.58)$. The efficiency of milk $\mathrm{C}$ output regards to $\mathrm{C}$ ingested was $25 \%$, on average.

Goats of the 2 groups ingested similar amounts of $\mathrm{N}$ $\left(2.6 \mathrm{~g} / \mathrm{kg}\right.$ of $\mathrm{BW}^{0.75}$, on average; SEM $\left.=0.18\right)$; Table 6 indicates a numerically lower intake in $\mathrm{RB}$ compared

Table 6. Carbon and nitrogen balance $\left(\mathrm{g} / \mathrm{kg}\right.$ of $\left.\mathrm{BW}^{0.75}\right)$ of MurcianoGranadina goats $(n=10)$ during late lactation according to the type of diet

\begin{tabular}{lrrrr}
\hline & \multicolumn{2}{c}{ Diet } & & $P$-value \\
\cline { 2 - 3 } & Oats & Rice bran & SEM & Diet \\
\hline Item $^{1}$ & 45.7 & 40.8 & 3.26 & 0.49 \\
$\mathrm{C}_{\text {intake }}$ & 14.0 & 10.6 & 1.09 & 0.13 \\
$\mathrm{C}_{\text {feces }}$ & 1.3 & 1.5 & 0.08 & 0.18 \\
$\mathrm{C}_{\text {urine }}$ & 16.4 & 14.8 & 0.66 & 0.25 \\
$\mathrm{C}_{\mathrm{CO} 2}$ & 1.7 & 1.3 & 0.14 & 0.04 \\
$\mathrm{C}_{\mathrm{CH} 4}$ & 10.6 & 11.2 & 0.76 & 0.73 \\
$\mathrm{C}_{\text {milk }}$ & 1.7 & 1.4 & 0.58 & 0.93 \\
$\mathrm{C}_{\text {retained body }}$ & 2.6 & 2.4 & 0.18 & 0.58 \\
$\mathrm{~N}_{\text {intake }}$ & 0.7 & 0.7 & 0.06 & 0.61 \\
$\mathrm{~N}_{\text {feces }}$ & 1.0 & 1.1 & 0.05 & 0.62 \\
$\mathrm{~N}_{\text {urine }}$ & 0.8 & 0.8 & 0.04 & 0.75 \\
$\mathrm{~N}_{\text {milk }}$ & 0.0 & -0.2 & 0.10 & 0.38 \\
$\mathrm{~N}_{\text {retained body }}$ & 0.2 & -1.0 & 0.44 & 0.41 \\
$\mathrm{R}_{\text {protein }}$ & 2.0 & 2.4 & 0.33 & 0.88 \\
$\mathrm{R}_{\text {fat }}$ & & & & \\
\hline
\end{tabular}

${ }^{1} \mathrm{C}_{\text {intake }}=\mathrm{C}$ intake; $\mathrm{C}_{\text {feces }}=\mathrm{C}$ losses in feces; $\mathrm{C}_{\text {urine }}=\mathrm{C}$ losses in urine $\mathrm{C}_{\mathrm{CO} 2}=\mathrm{C}$ losses in $\mathrm{CO}_{2} ; \mathrm{C}_{\mathrm{CH} 4}=\mathrm{C}$ losses in methane; $\mathrm{C}_{\text {milk }}=$ recovered $\mathrm{C}$ in milk; $\mathrm{C}_{\text {retained body }}=$ recovered $\mathrm{C}$ in tissue; $\mathrm{N}_{\text {intake }}=\mathrm{N}$ intake; $\mathrm{N}_{\text {feces }}$ $=\mathrm{N}$ losses in feces; $\mathrm{N}_{\text {urine }}=\mathrm{N}$ in urine; $\mathrm{N}_{\text {milk }}=$ recovered $\mathrm{N}$ in milk; $\mathrm{N}_{\text {retained body }}=$ recovered $\mathrm{N}$ in tissue; $\mathrm{R}_{\text {protein }}=$ retained protein; $\mathrm{R}_{\mathrm{fat}}=$ retained fat.

Journal of Dairy Science Vol. 99 No. 1, 2016 with $\mathrm{O}$. No differences were found in $\mathrm{N}$ losses in feces, urine, milk, and $\mathrm{N}$ retention. The ratio between milk $\mathrm{N}$ output and $\mathrm{N}$ ingested had an average value of 0.31 . We observed $\mathrm{N}$ retention around zero, and slightly negative $\mathrm{N}$ balance for RB (0.0 vs. $-0.2 \mathrm{~g} / \mathrm{kg}$ of $\mathrm{BW}^{0.75}$; SEM $=0.10$ ). Although some authors (Kebreab et al., 2010) report a reduction in urinary $\mathrm{N}$ output in dairy cows when ME intake increases, no differences were observed in our study in ME intake and urinary $\mathrm{N}$, despite the lower DMI observed with the RB diet. The negative $\mathrm{N}$ balance detected with $\mathrm{RB}$ is probably linked to a larger amount of $\mathrm{NH}_{3}-\mathrm{N}$ observed in the ruminal liquid, which would indicate an inefficient use of ruminal $\mathrm{NH}_{3}-\mathrm{N}$ for ruminal proteosynthesis (Casper et al., 1999) due to fat interference in microbial activity (Palmquist and Jenkins, 1980).

The values of $\mathrm{N}$ retained in the body were converted to grams of protein, and from this and the $\mathrm{C}$ balance value, grams of retention of fat were calculated. No differences were found between diets. As shown in Table 4, energy balance was positive, so $R_{\text {fat }}$ was also positive $\left(2.0\right.$ vs. $2.4 \mathrm{~g} / \mathrm{kg}$ of $\mathrm{BW}^{0.75}$, for $\mathrm{O}$ and $\mathrm{RB}$ respectively; $\mathrm{SEM}=0.33$ ) and hence no fat mobilization was observed. The negative $\mathrm{R}_{\text {protein }}$ in diet $\mathrm{RB}(-1.0 \mathrm{~g} /$ $\mathrm{kg}$ of $\mathrm{BW}^{0.75}$ ) was shown previously (Van Knegsel et al., 2007).

\section{Milk Production, Fatty Acids, and Metabolites}

Table 7 reports milk yield and milk metabolites of goats during the experiment. Diet had no effect on milk yield; average milk yield was $2,196.4 \pm 125.0 \mathrm{~g} / \mathrm{d}$. Chilliard et al. (2003) observed that fat supplementation increases milk yield in dairy cows, but not in goats, and increases milk fat content in goats, but not always in dairy cows. The replacement of oat (cereal grain with high fiber content) with rice bran (fibrous byproduct with less fiber content than oat) made the $\mathrm{O}$ diet greater in fiber compared with the RB diet. Increased milk fat content is common when dietary fiber concentrations increase at the expense of starch, but in our study, milk fat content was high in RB compared with O. The added bypass fat might be responsible for the significant differences $(P<0.01)$ in milk DM $(14.9$ and $16.4 \%$, for $\mathrm{O}$ and $\mathrm{RB}$, respectively; $\mathrm{SEM}=0.39)$ and milk fat content $(5.3$ and $6.9 \%$, for $\mathrm{O}$ and $\mathrm{RB}$, respectively; SEM =0.36). Further, in all studies reviewed by Chilliard et al. (2003), milk fat content increased with almost all studied fat supplements in goats but not in cows because their lipolytic systems differ. Milk protein and lactose contents were not statistically different among treatments $[4.0 \%, \mathrm{SEM}=0.12$, and $4.8 \%$, SEM $=0.08$, on average, for protein and lactose contents, respectively). Again, we observe that fat supplementa- 
Table 7. Daily milk production, composition, and metabolites of Murciano-Granadina goats ( $\mathrm{n}=10)$ during late lactation according to the type of diet

\begin{tabular}{|c|c|c|c|c|}
\hline \multirow[b]{2}{*}{ Item } & \multicolumn{2}{|c|}{ Diet } & \multirow[b]{2}{*}{ SEM } & \multirow{2}{*}{$\frac{P \text {-value }}{\text { Diet }}$} \\
\hline & Oats & Rice bran & & \\
\hline Milk production, $\mathrm{g} / \mathrm{d}$ & $2,244.5$ & $2,148.2$ & 125.03 & 0.729 \\
\hline \multicolumn{5}{|l|}{ Composition, \% } \\
\hline $\mathrm{DM}$ & 14.9 & 16.4 & 0.39 & 0.04 \\
\hline Fat & 5.3 & 6.9 & 0.36 & 0.01 \\
\hline Protein & 4.0 & 4.1 & 0.12 & 0.91 \\
\hline Lactose & 4.9 & 4.7 & 0.08 & 0.30 \\
\hline \multicolumn{5}{|l|}{ Milk metabolites } \\
\hline $\mathrm{BHB}, \mu \mathrm{mol} / \mathrm{L}$ & 55.3 & 54.0 & 2.92 & 0.83 \\
\hline Glucose, $\mathrm{mmol} / \mathrm{L}$ & 0.17 & 0.13 & 0.010 & 0.05 \\
\hline Glucose-6-phosphate, mmol/L & 0.14 & 0.10 & 0.010 & 0.02 \\
\hline Isocitrate, $\mathrm{mmol} / \mathrm{L}$ & 0.08 & 0.08 & 0.004 & 0.38 \\
\hline Uric acid, $\mu \mathrm{mol} / \mathrm{L}$ & 40.5 & 58.4 & 7.64 & 0.27 \\
\hline Milk urea, $\mathrm{mmol} / \mathrm{L}$ & 2.8 & 2.4 & 0.12 & 0.06 \\
\hline
\end{tabular}

tion decreases milk protein content in dairy cows but not in goats.

Analysis of milk metabolites indicated that the 2 diets provided goats with enough energy for their production levels; consequently, the values of the energy indicators $[\mathrm{BHB}$ and citrate, with average values of $54.7 \mathrm{mmol} / \mathrm{L}(\mathrm{SEM}=2.92)$ and $0.08 \mathrm{mmol} / \mathrm{L}(\mathrm{SEM}$ $=0.004)$, respectively] were in the normal range, consistent with those obtained by others authors (BjerreHarpøth et al., 2012). Glucose is the main precursor for lactose synthesis in the mammary gland (Linzell, 1968), and a higher $(P<0.05)$ value was found for $\mathrm{O}$ than for $\mathrm{RB}(0.17$ vs. $0.13 \mathrm{mmol} / \mathrm{L}$, respectively; $\mathrm{SEM}=$ 0.010). Palmquist and Jenkins (1980) reported reductions in blood glucose and insulin when protected lipids replaced concentrate. No differences were observed in the potential biomarkers in milk or indicators of rumen $\mathrm{N}$ flow, such as uric acid and urea in milk $[49.6 \mu \mathrm{mol} / \mathrm{L}$ $(\mathrm{SEM}=7.64)$ and $2.6 \mathrm{mmol} / \mathrm{L}(\mathrm{SEM}=0.12)$ on average, respectively].

Effects of diet on the fatty acid profile of milk fat are shown in Table 8. Compared with cow milk, goat milk is higher in medium-chain fatty acids (caprylic acid and, especially, capric acid). Medium-chain fatty acids contents were higher $(P<0.05)$ with the $\mathrm{O}$ diet compared with the $\mathrm{RB}$ diet: capric acid, undecanoic acid, myristic acid, myristoleic acid, and pentadecanoic acid. Undecanoic acid and pentadecanoic acid are potential biomarkers of rumen function because they are found in rumen bacterial lipids and might be partially synthesized endogenously from rumen substrates in the mammary gland (Vlaeminck et al., 2006, 2015; Fievez et al., 2012). The differences between treatments (lower contents of those fatty acids in the milk of RB goats) suggest a negative effect of $\mathrm{RB}$ oil on rumen bacterial metabolism, both de novo synthesis of bacterial lipids and fermentative activity. Our ammonia- $\mathrm{N}$ results in rumen liquid were in accordance with the differences observed in these fatty acids. Higher values $(P<0.05)$ were found for oleic acid and arachidic acid in RB compared with O. Thus, significant differences were found in medium-chain fatty acids (17.17 vs. $12.90 \mathrm{~g} / 100 \mathrm{~g}$ for $\mathrm{O}$ and $\mathrm{RB}$, respectively; $\mathrm{SEM}=0.969)$ and for MUFA (20.63 vs. $28.29 \mathrm{~g} / 100 \mathrm{~g}$ for $\mathrm{O}$ and $\mathrm{RB}$, respectively; SEM $=1.973$ ). No significant differences were found in CLA between diets. Hence, milk from goats fed the RB diet was the highest in MUFA, and goats fed the $\mathrm{O}$ diet had milk with more medium-chain fatty acids. Fatty acids with 16 or fewer carbon atoms derive from de novo synthesis, whereas those with 18 or more carbons atoms come from the diet or from lipid mobilization (Chilliard et al., 2003). In the present experiment, under positive energy balance, recovered energy in tissue was positive (Table 4) and retained fat was positive (Table 6 ). The atherogenicity index (calculated as $\mathrm{C} 12: 0+4$ $\times$ C14:0 + C16:0/UFA) was calculated as according to Ulbricht and Southgate (1991). The milk of goats fed the RB diet had a lower atherogenicity index than that of goats fed the $\mathrm{O}$ diet (2.17 vs. 3.50 on average, respectively; $\mathrm{SEM}=0.248$ ).

\section{Methane Emissions}

The effects of diet on $\mathrm{CH}_{4}$ emissions are shown in Table 9 . Goats fed the RB diet produced significantly $(P<0.05)$ less $\mathrm{CH}_{4}(23.2 \mathrm{~g} / \mathrm{d})$ than those on the $\mathrm{O}$ diet $(30.1 \mathrm{~g} / \mathrm{d} ; \mathrm{SEM}=2.14)$. The inhibition of $\mathrm{CH}_{4}$ production is normally accompanied by an increase in propionate production, which uses hydrogen and lactic acid. Cao et al. (2010) fed sheep fermented (high in lactic acid) and nonfermented TMR containing whole-crop rice and rice bran and although the fermented mixed 
Table 8. Fatty acid composition ( $\mathrm{g} / 100 \mathrm{~g}$ of identified fatty acids) of milk fat for Murciano-Granadina goats $(\mathrm{n}=10)$ during late lactation according to the type of diet

\begin{tabular}{|c|c|c|c|c|}
\hline \multirow[b]{2}{*}{ Item } & \multicolumn{2}{|c|}{ Diet } & \multirow[b]{2}{*}{ SEM } & \multirow{2}{*}{$\frac{P \text {-value }}{\text { Diet }}$} \\
\hline & Oats & Rice bran & & \\
\hline $\mathrm{C} 4: 0$ & 0.33 & 0.34 & 0.023 & 0.893 \\
\hline C6:0 & 1.06 & 0.97 & 0.072 & 0.570 \\
\hline C8:0 & 1.99 & 1.68 & 0.139 & 0.297 \\
\hline C10:0 & 9.61 & 6.81 & 0.680 & 0.027 \\
\hline C11:0 & 0.30 & 0.21 & 0.021 & 0.034 \\
\hline C12:0 & 4.20 & 3.23 & 0.593 & 0.452 \\
\hline C14:0 & 10.57 & 7.76 & 0.597 & 0.006 \\
\hline C14:1 & 0.17 & 0.12 & 0.010 & 0.004 \\
\hline $\mathrm{C} 15: 0$ & 0.11 & 0.08 & 0.008 & 0.002 \\
\hline C16:0 & 37.81 & 34.63 & 1.866 & 0.434 \\
\hline C16:1 & 0.92 & 0.91 & 0.050 & 0.948 \\
\hline $\mathrm{C} 17: 0$ & 0.53 & 0.48 & 0.053 & 0.677 \\
\hline $\mathrm{C} 17: 1$ & 0.21 & 0.23 & 0.035 & 0.738 \\
\hline C18:0 & 9.70 & 14.25 & 1.278 & 0.072 \\
\hline C18:1n-9 trans & 1.40 & 0.27 & 0.316 & 0.070 \\
\hline C18:1n-9 cis & 19.38 & 27.15 & 1.957 & 0.037 \\
\hline C18:1n-7 & 0.37 & 0.35 & 0.031 & 0.810 \\
\hline $\mathrm{C} 18: 2 \mathrm{n}-6$ cis & 3.21 & 3.30 & 0.189 & 0.815 \\
\hline C20:0 & 0.18 & 0.30 & 0.027 & 0.014 \\
\hline C18:3n-6 & 0.01 & 0.00 & 0.004 & 0.731 \\
\hline C20:1 & 0.15 & 0.11 & 0.017 & 0.176 \\
\hline C18:3n-3 & 0.32 & 0.28 & 0.017 & 0.284 \\
\hline CLA cis-9,trans- $11+$ trans- 9, cis- 11 & 0.70 & 1.19 & 0.156 & 0.124 \\
\hline CLA trans-10,cis-12 & 0.02 & 0.01 & 0.002 & 0.093 \\
\hline C20:4n-6 & 0.21 & 0.17 & 0.014 & 0.196 \\
\hline Medium-chain fatty acids & 17.17 & 12.90 & 0.969 & 0.015 \\
\hline MUFA & 20.63 & 28.29 & 1.973 & 0.043 \\
\hline PUFA & 3.74 & 3.76 & 0.196 & 0.966 \\
\hline SFA & 75.46 & 69.96 & 3.579 & 0.483 \\
\hline Atherogenicity index ${ }^{1}$ & 3.50 & 2.17 & 0.248 & 0.001 \\
\hline
\end{tabular}

${ }^{1}$ Atherogenicity index calculated as C12:0 $+4 \times$ C14:0 + C16:0/UFA(Ulbricht and Southgate, 1991).

ration increased digestibility, it decreased ruminal $\mathrm{CH}_{4}$ emission from 28.3 to $21.2 \mathrm{~g} / \mathrm{d}$ as a result of the conversion from lactic acid to propionic acid in the rumen.

According to Johnson and Johnson (1995), fermentation of fibrous carbohydrates produces more $\mathrm{CH}_{4}$ than fermentation of soluble sugars, which in turn produces more $\mathrm{CH}_{4}$ than fermentation of starch. As discussed previously, structural carbohydrates, NFC, and starch were lower in the $\mathrm{RB}$ than the $\mathrm{O}$ diet (5.6 points lower

Table 9. Methane emission of Murciano-Granadina goats $(\mathrm{n}=10)$ during late lactation according to the type of diet

\begin{tabular}{|c|c|c|c|c|}
\hline \multirow[b]{2}{*}{ Item $^{1}$} & \multicolumn{2}{|c|}{ Diet } & \multirow[b]{2}{*}{ SEM } & \multirow{2}{*}{$\frac{P \text {-value }}{\text { Diet }}$} \\
\hline & Oats & Rice bran & & \\
\hline $\mathrm{CH}_{4}, \mathrm{~g} / \mathrm{d}$ & 30.1 & 23.2 & 2.14 & 0.05 \\
\hline $\mathrm{Ym}, \%$ & 5.2 & 4.3 & 0.47 & 0.39 \\
\hline $\mathrm{CH}_{4} / \mathrm{DMI}, \mathrm{g} / \mathrm{kg}$ & 16.7 & 15.0 & 1.52 & 0.61 \\
\hline $\mathrm{CH}_{4} / \mathrm{OMd}, \mathrm{g} / \mathrm{kg}$ & 25.6 & 21.8 & 2.59 & 0.50 \\
\hline $\mathrm{CH}_{4} / \mathrm{NDFd}, \mathrm{g} / \mathrm{kg}$ & 236.2 & 137.1 & 46.02 & 0.32 \\
\hline $\mathrm{CH}_{4} / \mathrm{milk}, \mathrm{g} / \mathrm{kg}$ & 13.6 & 11.1 & 1.16 & 0.31 \\
\hline
\end{tabular}

${ }^{1} \mathrm{Ym}=$ methane energy/gross energy intake; OMd = digested $\mathrm{OM}$ $\mathrm{NDFd}=$ digested NDF. for NDF, NFC, and starch, on average), and the main difference was the higher lipid content in the RB diet (11.7 vs. $4.1 \%$ for $\mathrm{RB}$ and $\mathrm{O}$ diets, respectively). Fat content on the $\mathrm{RB}$ diet explains the $\mathrm{CH}_{4}$ mitigation observed in this diet. Feeding a diet with added lipids is one way to lower enteric $\mathrm{CH}_{4}$ emissions by ruminants (Knapp et al., 2014). Increasing the lipid content of the diet is acknowledged as a $\mathrm{CH}_{4}$ mitigation strategy due to reduction of methanogenesis and biohydrogenation of UFA (alternative sink of $\mathrm{H}_{2}$ ). Moreover, $\mathrm{CH}_{4}$ output is positively correlated with milk fatty acids C6:0 to C16:0 (Fievez et al. 2012), which result mainly from mammary de novo synthesis, based primarily on the use of acetate produced in the rumen during fiber digestion, and fatty acids ranged from C6:0 to C16:0, lower in the RB diet due to lower fermentation activity (Table 8).

Methane conversion ratio (the Ym factor) represents energy loss as $\mathrm{CH}_{4}$ per unit of GE intake; for both diets, it averaged $4.7 \%(\mathrm{SEM}=0.47)$. Although in the literature $\mathrm{CH}_{4}$ emissions are commonly expressed relative to GE intake, the most meaningful expression is relative to intake of $\mathrm{OM}$. In the present work, $\mathrm{CH}_{4}$ production 
expressed relative to DMI, digested OM, digested NDF, or kilograms of milk produced was not significant.

\section{CONCLUSIONS}

The total replacement of oat grain with rice bran (higher in lipids content than oat grain) reduced DMI by $12 \%$ without affecting milk yield $(2.2 \mathrm{~kg} / \mathrm{d}$, on average) in Murciano-Granadina goats during late lactation. This was accompanied by increases in ammonia $\mathrm{N}$ concentration in the rumen liquor and might suggest partial inhibition of microbial synthesis by the rice bran fat. The differences found between treatments (lower contents of undecanoic acid and pentadecanoic acid in milk of goats fed rice bran) suggest a negative effect of rice bran oil on rumen bacterial metabolism; that is, on both de novo synthesis of bacterial lipids and fermentation activity. Enteric $\mathrm{CH}_{4}$ emissions were reduced 6.9 $\mathrm{g} / \mathrm{d}$ by the diet that incorporated rice bran. Milk fat content and MUFA increased when rice bran was incorporated in the diet, so lactating goats could utilize rice bran diets without detrimental effects on milk performance. Additional studies evaluating rice bran without any bypass fat added should be considered.

\section{ACKNOWLEDGMENTS}

This study was supported by Instituto Nacional de Investigaciones Agrarias Project, Madrid, Spain (ref. RTA2014-00046-C02-02).

\section{REFERENCES}

AFRC (Agricultural and Food Research Council). 1993. Energy and Protein Requirements of Ruminants. CAB International, Wallingford, UK.

Aguilera, J. F., and C. Prieto. 1986. Description and function of an open-circuit respiration plant for pigs and small ruminants and the techniques used to measure energy metabolism. Arch. Tierernahr. 36:1009-1018.

Aguilera, J. F., C. Prieto, and J. Fonollá. 1990. Protein and energy metabolism of lactating Granadina goats. Br. J. Nutr. 63:165-175.

AOAC International. 2000. Official Methods of Analysis. 18th ed. AOAC International, Arlington, VA.

Batey, I. L. 1982. Starch analysis using thermostable alpha-amylases. Starch/Die Stärke 34:125-128.

Bava, L., L. Rapetti, G. M. Crovetto, A. Tamburini, A. Sandrucci, G. Galassi, and G. Succi. 2001. Effect of a non-forage diet on milk production, energy and nitrogen metabolism in dairy goats throughout lactation. J. Dairy Sci. 84:2450-2459.

Bjerre-Harpøth, V., N. C. Friggens, V. M. Thorup, T. Larsen, B. M. Damgaard, K. L. Ingvartsen, and K. M. Moyes. 2012. Metabolic and production profiles of dairy cows in response to decreased nutrient density to increase physiological imbalance at different stages of lactation. J. Dairy Sci. 95:2362-2380. PubMed

Brockway, J. M., A. W. Boyne, and J. G. Gordon. 1971. Simultaneous calibration of gas analyzers and meters. J. Appl. Physiol. 31:296-297.

Brouwer, E. 1958. On simple formulae for calculating the heat expenditure and the quantities of carbohydrate and fat metabolized in ruminants, from data on gaseous exchange and urine N. Pages 182-194 in Proc. 1st Symp. Energy Metabolism. EAAP Publ. 8. Academic Press, London, UK.

Brouwer, E. 1965. Report of sub-committee on constants and factors. Pages 441-443 in Proc. 3rd Symp. Energy Metabolism. K. L. Blaxter, ed. EAAP Publ. 11. Academic Press, London, UK.

Calsamiglia, S., A. Bach, C. de Blas, C. Fernández, and P. GarcíaRebollar. 2009. Nutritional requirements for dairy ruminants. Fundación Española para el Desarrollo de la Nutrición Animal (FEDNA). Madrid, Spain.

Cao, Y.. T. Takahashi, K. Horiguchi, N. Yoshida, and Y. Cai. 2010. Methane emissions from sheep fed fermented or non fermented total mixed ration containing whole-crop rice and rice bran. Anim. Feed Sci. Technol. 157:72-78.

Casper, D. P., H. A. Maiga, M. J. Brouk, and D. J. Schingoethe. 1999. Synchronization of carbohydrate and protein sources on fermentation and passage rates in dairy cows. J. Dairy Sci. 82:1779-1790.

Chilliard, Y., A. Ferlay, J. Rouel, and G. Lamberet. 2003. A review and nutritional and physiological factors affecting goat milk lipids synthesis and lipolysis. J. Dairy Sci. 86:1751-1770.

Chwalibog, A., A. H. Tauson, and G. Thorbek. 1997. Quantitative oxidation of nutrients in growing calves. Z. Ernahrungswiss. 36:313316.

Elliot, R., H. M. Ferreiro, A. Priego, and T. R. Preston. 1978. Estimate of the quantity of feed protein escaping degradation in rumen of steers fed chopped sugar cane, molasses/urea supplemented with varying quantities of rice polishing. Trop. Anim. Prod. 3:36-39.

European Union. 2003. Protection of animals used for experimental purposes. Council Directive 86/609/EEC of 24 November 1986, amended 16.9.2003. European Council, Brussels, Belgium.

Fahey, G. C., and L. L. Berger. 1988. Carbohydrate nutrition of ruminants. Pages 269-297 in The Ruminant Animal: Digestive Nutrition and Physiology. D. C. Church, ed. Prentice-Hall, Englewood Cliffs, NJ.

FAOSTAT. 2014. FAO Statistical Database, Food and Agricultural Organization of the United Nations, Rome, Italy. Accessed Dec. 15, 2014. http://faostat.fao.org/

FEDNA. 2010. Tablas de composición y valor nutritivo de alimentos para la fabricación de piensos compuestos. 3rd ed. Fundación Española Desarrollo Nutrición Animal (FEDNA), Madrid, Spain.

Fernández, C., M. C. López, and M. Lachica. 2012. Description and function of a mobile open-circuit respirometry system to measure gas exchange in small ruminants. Anim. Feed Sci. Technol. $172: 242-246$

Fernández, C., M. C. López, and M. Lachica. 2015. Low cost opencircuit hood system for measuring gs exchange in small ruminants: From manual to automatic recording. J. Agric. Sci. 153:1302-1309.

Fievez, V., E. Colman, J. M. Castro-Montolla, I. Stefanov, and B. Vlaeminck. 2012. Milk odd- and branched-chain fatty acids as biomarkers of rumen function-An update. Anim. Feed Sci. Technol. 172:51-65.

Forster, L. A., A. L. Goetsch, D. L. Galloway, W. Sun, A. R. Patil, and Z. B. Johnson. 1994. Digestion characteristics feed intake and live weight gain by cattle consuming forage supplemented with defatted rice bran or other feedstuffs. Anim. Feed Sci. Technol. $47: 259-275$.

Johnson, K. A., and D. E. Johnson. 1995. Methane emissions in cattle. J. Anim. Sci. 73:2483-2492.

Jouany, J. P. 1982. Volatile fatty acid and alcohol determination in digestive contents, silage juices, bacterial cultures and anaerobic fermentor contents. Sci. Aliments 2:131-144.

Kebreab, E., A. B. Strathe, J. Dijkstra, J. A. N. Mills, C. K. Reynolds, L. A. Crompton, T. Yan, and J. France. 2010. Energy and protein interactions and their effects on nitrogen excretion in dairy cows. Pages 417-426 in Symp. Energy and Protein Metabolism and Nutrition, Parma, Italy. Wageningen Academic Publishers, Wageningen, the Netherlands.

Knapp, J. R., G. L. Laur, P. A. Vadas, W. P. Weiss, and J. M. Tricarico. 2014. Invited review: Enteric methane in dairy cattle production: Quantifying the opportunities and impact of reducing emissions. J. Dairy Sci. 97:3231-3261. 
Lachica, M., and J. F. Aguilera. 2003. Estimation of energy needs in the free-ranging goat with particular reference to the assessment of its energy expenditure by the ${ }^{13} \mathrm{C}$-bicarbonate method. Small Rumin. Res. 49:303-318.

Larsen, T., and K. M. Moyes. 2010. Fluorometric determination of uric acid in bovine milk. J. Dairy Res. 77:438-444.

Larsen, T., and N. I. Nielsen. 2005. Fluorometric determination of $\beta$ hydroxybutyrate in milk and blood plasma. J. Dairy Sci. 88:20042009.

Linzell, J. L. 1968. The magnitude and mechanisms of the uptake of milk precursors by the mammary gland. Proc. Nutr. Soc. 27:44-52.

Lunsin, R., M. Wanapat, C. Yuangklang, and P. Rowlinson. 2012. Effect of rice bran oil supplementation on rumen fermentation, milk yield and milk composition in lactating dairy cows. Livest. Sci. 145:167-173.

McLean, J. A., and G. Tobin. 1987. Animal and Human Calorimetry. Cambridge University Press, Cambridge, UK

Mertens, D. R. 2002. Gravimetric determination of amylase-treated neutral detergent fibre in feeds with refluxing beakers or crucibles: collaborative study. J. AOAC Int. 85:1217-1240.

Moraes, L. E., E. Kebreab, A. B. Strathe, J. Dijkstra, J. France, D. P. Casper, and J. G. Fadel. 2015. Multivariate and univariate analysis of energy balance data from lactating dairy cows. J. Dairy Sci. 98:4012-4029.

NRC. 2001. Nutrient Requirements of Dairy Cattle. 7th rev. ed. Natl. Acad. Press, Washington, DC.

O'Fallon, J. V., J. R. Busboom, M. L. Nelson, and C. T. Gaskins, 2007. A direct method for fatty acid methyl ester synthesis: Application to wet meat tissues, oils, and feedstuffs. J. Anim. Sci. 85:1511-1521.

Oliveira, M. S., V. Feddern, L. Kupski, E. P. Cipolatti, E. Badiale-Furlong, and L. A. Souza-Soares. 2011. Changes in lipid, fatty acids and phospholipids composition of whole rice bran after solid-stage fungal fermentation. Bioresour. Technol. 102:8335-8338.

Ørskov, E. R., and C. Fraser. 1975. The effects of processing of barleybased supplements on rumen $\mathrm{pH}$, rate of digestion and voluntary intake of dried grass in sheep. Br. J. Nutr. 34:493-500.
Palmquist, D. L., and T. C. Jenkins. 1980. Fat in lactation rations. J. Dairy Sci. 63:1-14. (Review).

Romero-Huelva, M., E. Ramos-Morales, and E. Molina-Alcaide. 2012. Nutrient utilization, ruminal fermentation, microbial abundances, and milk yield and composition in dairy goats fed diets including tomato and cucumber waste fruits. J. Dairy Sci. 95:6015-6026.

SAS Institute. 2001. User's Guide. Version 8.02. SAS Institute Inc. Cary, NC.

Tovar-Luna, I., R. Puchala, T. Sahlu, H. C. Freetly, and A. L. Goetsch. 2010. Effects of stage of lactation and dietary concentrate level on energy utilization by Alpine dairy goats. J. Dairy Sci. 93:4818 4828

Ulbricht, T. L., and D. A. T. Southgate. 1991. Coronary heart disease: Seven dietary factors. Lancet 338:985-992.

Van Knegsel, A. T. M., H. Brand, J. Dijkstra, W. M. Straalen, M. J. W. Heetkamp, S. Tamminga, and B. Kemp. 2007. Dietary energy source in dairy cows in early lactation: Energy partitioning and milk composition. J. Dairy Sci. 90:1467-1476.

Van Soest, P. J. 2006. Rice straw, the role of silica and treatments to improve quality. Anim. Feed Sci. Technol. 130:137-171.

Vlaeminck, B., V. Fievez, A. R. J. Cabrita, A. J. M. Fonseca, and R. J. Dewhurst. 2006. Factors affecting odd-and branched-chain fatty acids in milk: A review. Anim. Feed Sci. Technol. 131:389-417.

Vlaeminck, B., R. Gervais, M. M. Rahman, F. Gadeyne, M. Gorniak, M. Doreau, and V. Fievez. 2015. Postruminal synthesis modifies the odd- and branched-chain fatty acid profile from the duodenum to milk. J. Dairy Sci. 98:4829-4840.

Warren, B. E., and D. J. Farrell. 1990. The nutritive value of full fat and defatted Australian rice bran. I. Chemical composition. Anim. Feed Sci. Technol. 27:219-228.

Zhao, Y., K. Taniguchi, and T. Obitsu. 1996. Effects of different processing procedures for rice bran on dietary nutrient digestion in each segment of the digestive tract of steers. Anim. Feed Sci. Technol. 59:265-277. 